\title{
Screening of Selected Garlic Varieties Against White Rot Disease Caused by Sclerotium cepivorum at Dhaka City of Bangladesh
}

\author{
Umme Habiba Akter, ", Fatema Begum ${ }^{1}$, Md Rafiqul Islam¹, Mst Rehena Khatun ${ }^{1}$, \\ Md Mozidul Islam² \\ ${ }^{1}$ Department of Plant Pathology, Sher-e-Bangla Agricultural University, Dhaka, Bangladesh \\ ${ }^{2}$ Department of Agricultural Extension, Burihat, Rangpur, Bangladesh
}

Email address:

sumonahabiba31@gmail.com(U. H. Akter), fatema22_sau@yahoo.com (F. Begum), rafiqsau64@yahoo.com (Md R. Islam), rehenakhatun1213@gmail.com (M. R. Khatun),ddhcrangpur5400@gmail.com (Md M. Islam)

${ }^{*}$ Corresponding author

\section{To cite this article:}

Umme Habiba Akter, Fatema Begum, Md Rafiqul Islam, Mst Rehena Khatun, Md Mozidul Islam. Screening of Selected Garlic Varieties Against White Rot Disease Caused by Sclerotium cepivorum at Dhaka City of Bangladesh. American Journal of Plant Biology.

Vol. 6, No. 3, 2021, pp. 53-59. doi: 10.11648/j.ajpb.20210603.13

Received: July 14, 2021; Accepted: July 28, 2021; Published: August 4, 2021

\begin{abstract}
White rot caused by Sclerotium cepivorum fungus is a crucial soil borne disease on garlic damaging allium production globally including Bangladesh. In this study eight isolates of Sclerotium cepivorum were isolated from naturally infected garlic plants collected from the central farm and isolated in the central lab of Sher-e-Bangla Agricultural University, Dhaka, Bangladesh to determine the prevalence of white rot disease incidence and severity and characterized for cultural and morphological variabilities of the isolated pathogen. Eight garlic varieties viz. BAU Rashun-1, BAU Rashun-2, BARI Rashun1, BARI Rashun-2, BARI Rashun-3, BARI Rashun-4, Local Deshi and Local Indian were explored with three replication in the study. Results showed that the highest disease incidence and severity against white rot disease $(33.33 \%$ and $89.33 \%)$ were appeared in the BARI Rashun-3 variety. Lowest disease incidence and severity $(5.00 \%$ and $60 \%)$ were recorded on Local Indian variety. Almost all of the isolates had cottony fluffy growth on potato dextrose agar. The colony color varied from milky white to cottony watery white with regular, circular, smooth, cotton like sometimes striped surface texture was found. After 10 days of incubation all the isolates had suppressed growth on PDA media as it is a fast growing pathogen.
\end{abstract}

Keywords: Garlic White Rot, Sclerotium cepivorum, Disease Incidence, Disease Severity and Fungal Pathogen

\section{Introduction}

Garlic (Allium sativum L.) is an annual tuberous spice of the Alliaceae family next to onion that is inherent to Central and South Asia. For thousands of years garlic has been used as a functional food, spice and seasoning herb, as well as an effective, traditional medicine against different ailments including viral diseases. The highest garlic production countries in the world have been reported are China, India, South Korea, Egypt and USA [1]. Garlic is thought to be one of the most essential spice crops produced on a large scale in Bangladesh.

In spite of being a medicinal plant, garlic is attacked by various pathogenic agents that caused heavy economic losses to the crops. Among pathogenic agents particularly soil borne fungal pathogen Sclerotium cepivorum causes disease known as garlic white rot is a drastic yield reducing disease which prevalent in many Allium growing regions around the world [2-6]. The disease was first noticed in 1929 in Egypt [7] and then spread globally all over the world viz. Brazil [8], Netherlands, Spain, Switzerland, United Kingdom [9], Australia [10, 11], Canada [12], New Zealand [13], USA [14], Mexico [15], Iran [2] and Argentina [16].

Sclerotium cepivorum is the most devastating fungal pathogen and has critical concerns to the crops because once the sclerotia are in the soil; they can stable for up to 40 years in absence of host plant and for that it is difficult to control $[17,18]$. The pathogen has caused great damage in different 
garlic growing regions globally and causes serious reduction in the production of garlic crops. Earnshaw, Donald and Boland reported that white rot disease causes $100 \%$ yield loss in Mexico and Brazil [19]. Garlic and onion production were enforced to abandon by some growers of garlic growing regions in Minas Gerais and Sao Paulo states owing to presence of high levels of sclerotia in soil $[20,21]$. In the cultivated field of garlic of Northern Showa of Ethiopia, owing to white rot disease incidence ranging from $37.28 \%$ to $42 \%$ [22]. Mycelium of S. cepivorum spread from plant Vieira, Lopes and Villata stated that white rot of garlic causes total crop losses when sclerotia levels are high in soil and environmental conditions favorable for disease development [25].

White rot is a major production threat of garlic in Bangladesh. The United Nations Food and Agriculture Organization stated that from 1,634,634 hectares of world area harvested garlic produce about 30,708,243 tonnes of garlic globally each year [26]. Total production of Garlic in the year of 2019 in Bangladesh is 466, 389 tonnes from 71734 ha land with an average yield of $65,016 \mathrm{hg} / \mathrm{ha}$. Production of garlic is drastically reduced in presence of high amount of sclerotia in soil under favorable condition for disease development, inappropriate agronomic practices, imbalanced fertilizer, uneven irrigation and lac $\mathrm{k}$ of improved varieties [27]. The purpose of this current study was to assess the occurrence of white rot \% disease incidence and severity of selected garlic varieties under natural condition and isolate and identify the pathogen for morphological characterization.

\section{Materials and Methods}

\subsection{Description of the Experimental Site}

A field experiment were conducted during the Rabi season of 2019-2020 at the central farm of Sher-e-Bangla Agricultural University and in the central Laboratory, Department of Plant Pathology, Sher-e-Bangla Agricultural University, Dhaka, Bangladesh $\left(23^{\circ} 41^{\prime} \mathrm{N}\right.$ latitude and $90^{\circ} 22^{\prime} \mathrm{E}$ longitudes at the elevation of $8.6 \mathrm{~m}$ above the sea level, AEZ-28) on eight different varieties of garlic with three replications consists of 24 unit plots in Randomized complete block design (RCBD).

\subsection{Source of Garlic Cloves}

Eight several pure and disease-free garlic variety seed were culled from three different places. BAU Rashun-1 $\left(\mathrm{V}_{1}\right)$ and BAU Rashun-2 $\left(\mathrm{V}_{2}\right)$ varieties were brought from Bangladesh Agricultural University, Horticulture Department, Mymensingh. BARI Rashun-1 ( $\left.\mathrm{V}_{3}\right)$, BARI Rashun-2 $\left(\mathrm{V}_{4}\right)$, BARI Rashun-3 $\left(\mathrm{V}_{5}\right)$ and BARI Rashun-4 $\left(\mathrm{V}_{6}\right)$ varieties were collected from Bangladesh Agricultural Research Institute, Joydebpur, Gazipur and last two local varieties naming Local Deshi $\left(\mathrm{V}_{7}\right)$ and Indian Local $\left(\mathrm{V}_{8}\right)$ were collected from Siddik bazar, Dhaka, Bangledesh.

\subsection{Method of Data Collection}

The plant population in each plot was counted and average plant populations in three replications were considered as mean plant population density. Garlic varieties were observed on the basis of symptoms appeared on the above ground plants and disease incidence and severity was estimated by computing the number of plant showing white rot symptoms viz. yellowing, discoloration, rotten bulb, presence of sclerotia around the base of the plant etc.

\subsection{1. (\%) Disease Incidence}

To estimate the percent disease incidence each plant was counted including infected one in the field and then expressed in percentage. For the determination of disease incidence of garlic the following formula given by [28] was used.

$$
\% \mathrm{DI}=\frac{\text { Number of diseased plants }}{\text { Number of total plants observed }} \times 100
$$

\subsection{2. \% Disease Severity}

Disease severity of white rot was computed by observing the level of damage by the pathogen using 0-5 scale and converted to percentage as follows by selecting 10 plants randomly from each plot and used for PDI (percent disease index) estimation.

$\begin{array}{ll}\text { Grade } & \text { Symptoms description } \\ 0 & \text { No infection } \\ 1 & 1-10 \% \text { infection } \\ 2 & 11-20 \% \text { infection } \\ 3 & 21-30 \% \text { infection } \\ 4 & 31-50 \% \text { infection } \\ 5 & >50 \% \text { infection }\end{array}$

The percent disease index (PDI) was calculated according to the formula given by $[29,30]$.

$$
\mathrm{PDI}=\frac{\text { Total sum of numerical ratings }}{\text { Number of observations } \mathrm{x} \text { Maximum disease rating }} \chi 100
$$

\subsection{Isolation and Identification of Sclerotium Cepivorum}

Naturally infected garlic plant showing white rot symptoms were collected from the field, placed in brown paper and were transferred to the central laboratory, Department of Plant Pathology, Sher-e-Bangla Agricultural University, Dhaka for isolation of the pathogenic agent. Isolation process was performed by cutting the diseased leaves into pieces with the help of sterilized scalpel, washed with distilled water and surface sterilized using 0.1 percent $\mathrm{MgCl}_{2}$ solution (30 to 60 seconds) then were washed three times right away with double distilled water frequently to eradicate the certainty of mercuric chloride and dried with a towel on sterilized filter paper.

Disinfected leaves then placed to petridish containing 20 $\mathrm{ml}$ of autoclaved water agar (Agar $20 \mathrm{~g}$ with $1000 \mathrm{ml}$ distilled water) in a laminar flow and incubated at $25 \pm 1{ }^{\circ} \mathrm{C}$ near ultra-violate light for 10 days. After 10 days the growing mycelia on water agar petridish were transferred to potato dextrose agar media (200g of peeled potatoes, $20 \mathrm{~g}$ of dextrose, and $20 \mathrm{~g}$ of agar and $1000 \mathrm{ml}$ of distilled water). At 
10 days the fungus grew well and sporulated then freshly prepare slide was observed under compound microscope and digital microscope for the identification of the pathogen using relevant literature. The colonies of grown fungus were purified and pure culture were maintained by sub culturing at an interval every 15 days and preserved at low temperature $\left(4^{\circ} \mathrm{C}\right)$ in refrigerator for future purpose. The observations were computed with the standard measurements and the fungal isolates were identified following by [31] (Figure 1).
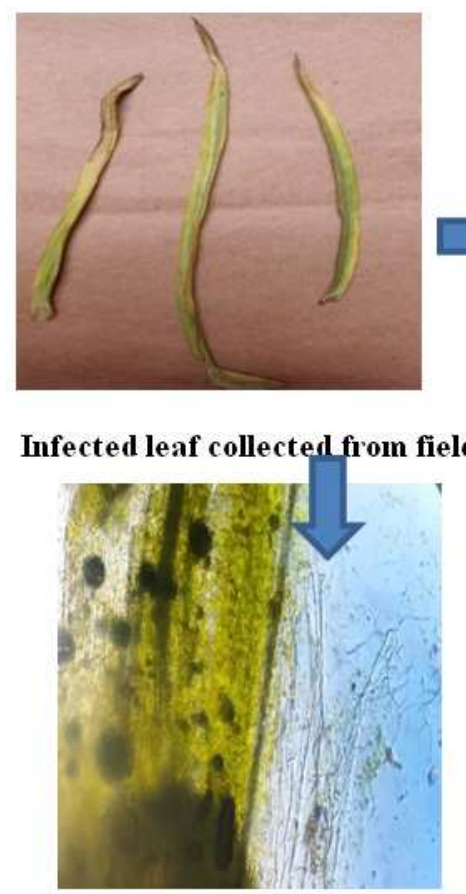

Mycelia under compound

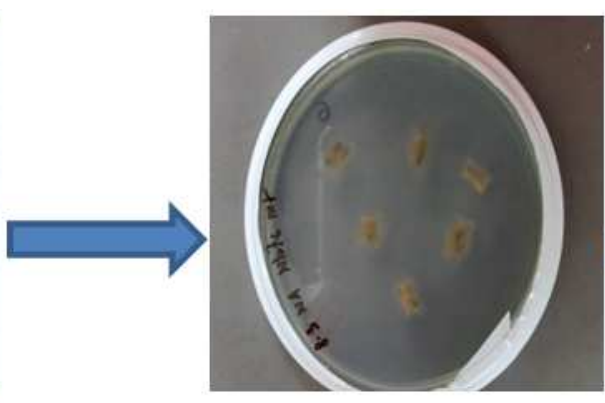

Mycelial growth on water agar

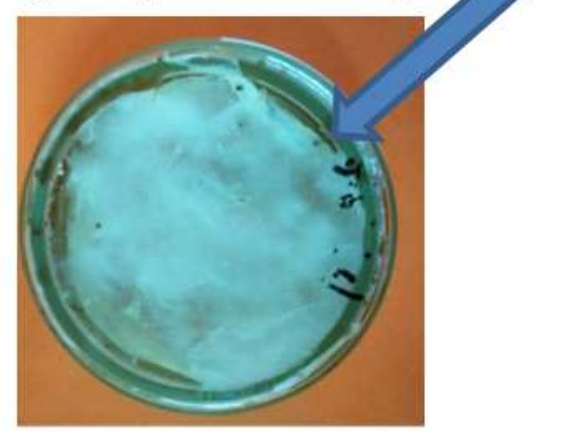

Sclerotia produced on PDA media

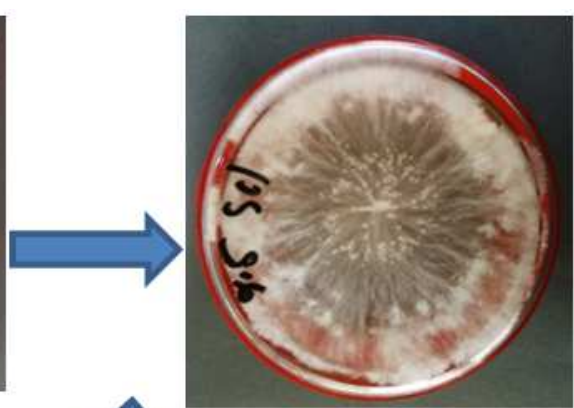

Pure culture on PDA media

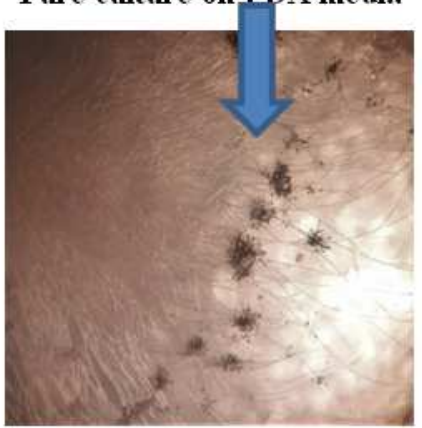

Mycelia under sterio microscope from pure culture

microscope from infected leaf

Figure 1. Flow chart of isolation, identification and pure culture of Sclerotium cepivorum.

\subsection{Designation of Cultured Isolates}

The cultured isolates were designated based on variety and location [32]. For example $\mathrm{BAU}_{1} \mathrm{I}_{1}$ represents that this isolate was cultured from BAU Rashun-1 variety.

\subsection{Cultural Variability of Sclerotium Cepivorum}

In cultural variation the colony diameter was recorded on the $2^{\text {nd }}, 7^{\text {th }}$ and $10^{\text {th }}$ days after incubation. The data on radial growth was analyzed statistically [33]. Growth per day was calculated by the followed formula:

$\mathrm{mm} /$ day $=($ growth observed on a day - growth on previous observation) $/ 2$.

\subsection{Morphological Variability of Sclerotium Cepivorum}

Ten days old cultures of $S$. cepivorum isolates were studied for morphological variations. In terms of conidia color, shape, size, colony character and surface structure were observed on PDA medium.

\subsection{Statistical Analysis}

The obtained data of different characters were subjected to statistically analyses to see the significant difference among mean using the MSTAT-C program. Conversions of the data were required when necessary. The mean values were then calculated and compared using Duncan's Multiple Range test. The least significant differences (LSD) at 5\% level of probability were used to separate the means within the parameters [34].

\section{Results}

\subsection{Evaluation of Selected Garlic Varieties Against White Rot Diseases at Field Condition}

White rot is generally introduced to garlic plants through contaminated plant materials or soil. Once a small area of the field is contaminated it gradually spread to healthy plants and soil. Initially the stunted plants of garlic were considered as the first sign of white rot. Yellow striped leaves were spotted on the top of the garlic plants and eventually stopped producing leaves. The infected leaves were decayed at the base, turn yellow, wilt, and toppled over older leaves. Roots of the plants were rotted, and the top of the plant can be pulled out of the ground easily. Fluffy white mycelium was found on the remaining roots and bulb. As the infected bulbs dries and shrinks the outer scales crack it became watery (Figure 2). 


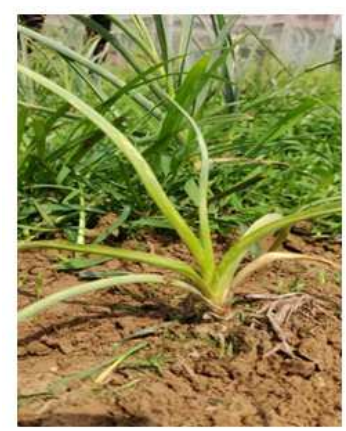

A.

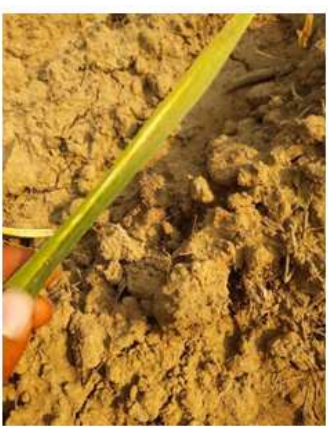

B.

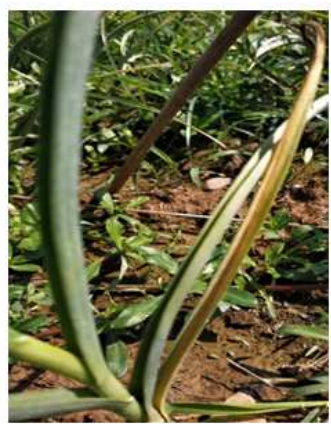

C.

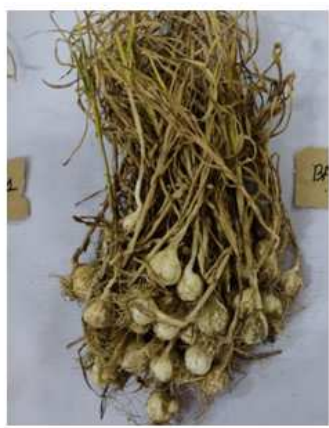

D.

Figure 2. Symptoms of white rot disease A. Symptoms on plants; B. Symptoms at early stage; C. Severe symptoms at late stage; D. Symptoms on harvested plant.

\subsection{Prevalence of \% Disease Incidence and Disease Severity of White Rot Disease Among Selected Garlic Varieties}

Though white rot of garlic prevailed on garlic plant after 45 days of sowing, data were collected concerning disease incidence and severity after 60 DAS. Percent disease incidence and severity on different varieties of garlic showed significant variation at 60 DAS and 90 DAS are shown in Table 1. The disease incidence varied from $5.00 \%$ to $33.33 \%$. Besides, the disease severity varied from $36.00 \%$ to $89.33 \%$.

At 60 DAS, BARI Rashun-3 scored the maximum disease incidence $(29.44 \%)$. The highest disease severity $(63.33 \%)$ was found on BARI Rashun-3 variety that was statistically similar to BARI Rashun-4 (58.67\%) variety, respectively. On the contrary, Local Indian variety gave the lowest disease incidence $(5.00 \%)$ which was statistically alike with BAU Rashun-2 (6.11\%). The lowest disease severity was noted $36.00 \%$ on Local Indian variety.

At 90 DAS, the highest disease incidence $(33.33 \%)$ and disease severity $(89.33 \%)$ was observed on BARI Rashun-3 variety. BARI Rashun- 4 gave the second highest disease incidence $(21.11 \%)$ and disease severity $(77.33 \%)$. On the other hand, Local Indian variety showed the lowest disease incidence $(5.00 \%)$ and disease severity $(60.00 \%)$ which was statistically similar to BAU Rashun-2 disease incidence of $6.11 \%$ and disease severity of $64.00 \%$.

Table 1. Prevalence of \% disease incidence and severity of white rot disease among selected garlic varieties.

\begin{tabular}{lllll}
\hline \multirow{2}{*}{ Variety } & \multicolumn{2}{l}{ (\%) Disease Incidence } & \multicolumn{2}{l}{ (\%) Disease severity } \\
\cline { 2 - 5 } 60 DAS & 90 DAS & 60 DAS & 90 DAS \\
\hline BAU Rashun-1 & $7.22 \mathrm{de}$ & $7.22 \mathrm{~d}-\mathrm{f}$ & $44.00 \mathrm{bc}$ & $63.33 \mathrm{c}$ \\
BAU Rashun-2 & $6.11 \mathrm{e}$ & $6.11 \mathrm{ef}$ & $47.33 \mathrm{bc}$ & $64.00 \mathrm{c}$ \\
BARI Rashun-1 & $9.44 \mathrm{~cd}$ & $9.44 \mathrm{~cd}$ & $46.67 \mathrm{bc}$ & $69.33 \mathrm{bc}$ \\
BARI Rashun-2 & $12.22 \mathrm{c}$ & $12.22 \mathrm{c}$ & $46.67 \mathrm{bc}$ & $70.67 \mathrm{bc}$ \\
BARI Rashun-3 & $29.44 \mathrm{a}$ & $33.33 \mathrm{a}$ & $63.33 \mathrm{a}$ & $89.33 \mathrm{a}$ \\
BARI Rashun-4 & $17.78 \mathrm{~b}$ & $21.11 \mathrm{~b}$ & $58.67 \mathrm{ab}$ & $77.33 \mathrm{~b}$ \\
Local Deshi & $7.22 \mathrm{de}$ & $8.33 \mathrm{de}$ & $44.00 \mathrm{bc}$ & $66.00 \mathrm{bc}$ \\
Local Indian & $5.00 \mathrm{e}$ & $5.00 \mathrm{f}$ & $36.00 \mathrm{c}$ & $60.00 \mathrm{c}$ \\
CV & 15.37 & 14.19 & 18.65 & 9.65 \\
\hline
\end{tabular}

$\mathrm{CV}=$ Coefficient of variance; in a column mean values having similar letter (s) are statistically similar and those having dissimilar letter (s) differ significantly as per $0.01 \%$ level of significance.

\subsection{Cultural Studies of Sclerotium Cepivorum}

Sclerotium cepivorum is a fast growing pathogen in PDA media. The reviews on colony shape and growth of the pathogens were noted for 10 consecutive days (Table 2).

Colony growth of the pathogen appeared after 2 days of inoculation. Maximum increase of colony diameter $(5.20$ $\mathrm{mm})$ was noted on $\mathrm{BAU}_{2} \mathrm{I}_{2}$ and $\mathrm{LD} \mathrm{I}_{7}$, respectively. Conversely, the minimum radial mycelial growth was observed on BARI $\mathrm{I}_{3}(4.10 \mathrm{~mm})$. After 7 days of inoculation, $\mathrm{BARI}_{3} \mathrm{I}_{5}$ scored $7.65 \mathrm{~mm}$ maximum colony diameter. The minimum increment of colony diameter $(6.00$ $\mathrm{mm}$ ) was found in $\mathrm{BARI}_{4} \mathrm{I}_{6}$. As the pathogen is fast growing, at $10 \mathrm{DAI}$ the maximum pathogen covered the whole petridish of $9.00 \mathrm{~mm}$ except BARI $\mathrm{I}_{3}(7.65 \mathrm{~mm})$ and $\mathrm{BARI}_{2}$ $\mathrm{I}_{4}(7.00 \mathrm{~mm})$.

Table 2. Radial mycelial growth of Sclerotium cepivorum.

\begin{tabular}{llll}
\hline \multirow{2}{*}{ Isolates } & \multicolumn{3}{l}{ Radial mycelial growth $(\mathbf{m m})$} \\
\cline { 2 - 4 } & 2 DAI & 7 DAI & 10 DAI \\
\hline $\mathrm{BAU}_{1} \mathrm{I}_{1}$ & 4.50 & 7.50 & 9.00 \\
$\mathrm{BAU}_{2} \mathrm{I}_{2}$ & 5.20 & 7.45 & 9.00 \\
$\mathrm{BARI}_{1} \mathrm{I}_{3}$ & 4.10 & 6.50 & 7.65 \\
$\mathrm{BARI}_{2} \mathrm{I}_{4}$ & 5.00 & 7.00 & 7.00 \\
$\mathrm{BARI}_{3} \mathrm{I}_{5}$ & 4.50 & 7.65 & 9.00 \\
$\mathrm{BARI}_{4} \mathrm{I}_{6}$ & 5.00 & 6.00 & 9.00 \\
$\mathrm{LD} \mathrm{I}_{7}$ & 5.20 & 7.45 & 9.00 \\
LIND $_{8}$ & 4.50 & 7.50 & 9.00 \\
\hline
\end{tabular}

In the column $\mathrm{BAU}_{1} \mathrm{I}_{1}=\mathrm{BAU}_{1}$ Isolate $_{1} ; \mathrm{BAU}_{2} \mathrm{I}_{2}=\mathrm{BAU}_{2}$ Isolate $_{2} ; \mathrm{BARI}_{1}$ $\mathrm{I}_{3}=\mathrm{BARI}_{1}$ Isolate $_{3} ; \mathrm{BARI}_{2} \mathrm{I}_{4}=\mathrm{BARI}_{2}$ Isolate $_{4} ; \mathrm{BARI}_{3} \mathrm{I}_{5}=\mathrm{BARI}_{3}$ Isolate ${ }_{5}$; BARI $_{4} \mathrm{I}_{6}=$ BARI $_{4}$ Isolate $_{6} ; \mathrm{LD} \mathrm{I}_{7}=$ Local Deshi Isolate 7 and LIND $\mathrm{I}_{8}=$ Local Indian Isolate 8

\subsection{Morphological Studies of Sclerotium Cepivorum}

The pure culture of pathogen S. cepivorum was observed regularly under the microscope for morphological characteristics viz. color, shape and surface texture (Table 3, Figure 3).

Almost all of the isolates had cottony fluffy growth on potato dextrose agar. The colony color varied from milky white to cottony watery white. Smooth, cotton like sometimes striped surface texture was found. After 10 days of incubation all the isolates except $\mathrm{BARI}_{1} \mathrm{I}_{3}$ and $\mathrm{BARI}_{2} \mathrm{I}_{4}$ 
had suppressed growth on PDA media as it is a fast growing pathogen. The shape of the colony was regular, circular. At

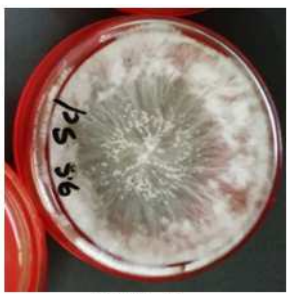

$\mathrm{BAU}_{1} \mathrm{I}_{1}$

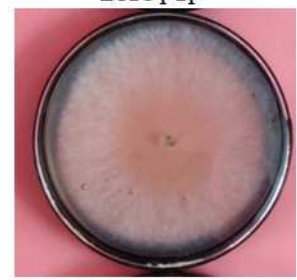

$\mathrm{BARI}_{3} \mathrm{I}_{5}$

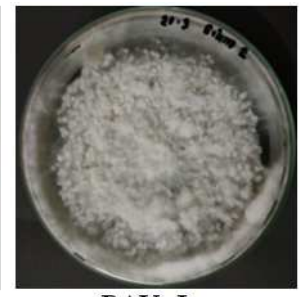

$\mathrm{BAU}_{2} \mathrm{I}_{2}$

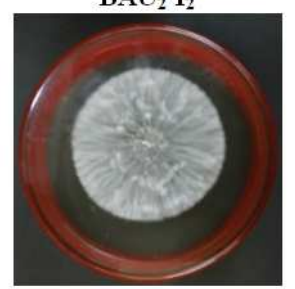

BARI $_{4} \mathrm{I}_{6}$ the full growth of $S$. cepivorum dark brown color cotton like sclerotia was found.

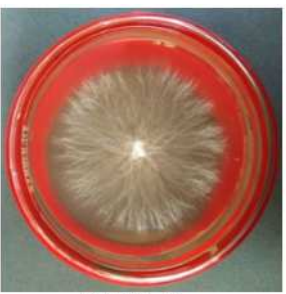

BARI $_{1} I_{3}$

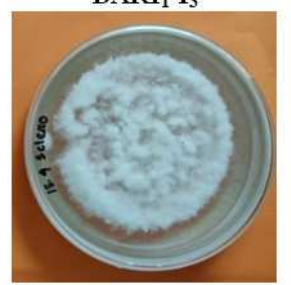

LD I 7

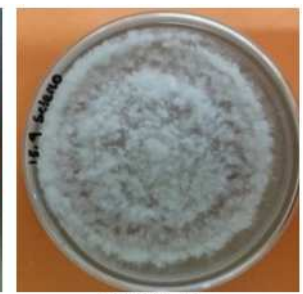

$\mathrm{BARI}_{2} \mathrm{I}_{4}$

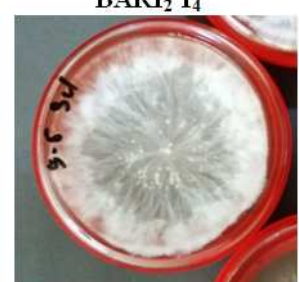

LIND I $_{8}$

Figure 3. Mycelial growth of Sclerotium cepivorum on PDA media at 10 days after incubation.

Table 3. Colony characteristics of Sclerotium cepivorum on PDA media.

\begin{tabular}{llll}
\hline \multirow{2}{*}{ Isolates } & \multicolumn{2}{l}{ Colony characteristics } & \\
\cline { 2 - 4 } & Color & Surface texture & Shape \\
\hline BAU $_{1} \mathrm{I}_{1}$ & Milky white & Fluffy & Regular \\
$\mathrm{BAU}_{2} \mathrm{I}_{2}$ & Milky white & Fluffy & Irregular \\
$\mathrm{BARI}_{1} \mathrm{I}_{3}$ & Watery white & Cottony & Regular \\
$\mathrm{BARI}_{2} \mathrm{I}_{4}$ & Cottony white & Cottony & Regular \\
$\mathrm{BARI}_{3} \mathrm{I}_{5}$ & Watery white & Cottony & Regular \\
$\mathrm{BARI}_{4} \mathrm{I}_{6}$ & Milky white & Fluffy & Regular \\
$\mathrm{LD} \mathrm{I}_{7}$ & Cottony white & Cottony & Regular \\
$\mathrm{LIND} \mathrm{I}_{8}$ & Milky white & Fluffy & Irregular \\
\hline
\end{tabular}

In the column $\mathrm{BAU}_{1} \mathrm{I}_{1}=\mathrm{BAU}_{1}$ Isolate $_{1} ; \mathrm{BAU}_{2} \mathrm{I}_{2}=\mathrm{BAU}_{2}$ Isolate $_{2} ; \mathrm{BARI}_{1}$ $\mathrm{I}_{3}=\mathrm{BARI}_{1}$ Isolate $_{3} ; \mathrm{BARI}_{2} \mathrm{I}_{4}=\mathrm{BARI}_{2} \quad$ Isolate $_{4} ; \mathrm{BARI}_{3} \mathrm{I}_{5}=\mathrm{BARI}_{3}$ Isolate Is $_{5}$; $\mathrm{BARI}_{4} \mathrm{I}_{6}=\mathrm{BARI}_{4}$ Isolate $_{6} ; \mathrm{LD} \mathrm{I}_{7}=$ Local Deshi Isolate ${ }_{7}$ and LIND $\mathrm{I}_{8}=$ Local Indian Isolate 8

\section{Discussions}

White rot showed stunted plant growth, followed by yellowing and death of the outer leaves. In severe cases the bulb completely rotten. Similar symptoms were found in Painter, Woodhall and Jenson where initially, infected plants showed yellowing and wilting of the leaves, starting with the older leaves [35]. Tamire, Cemeda, Sakuja and Seid stated that constant growing of garlic leads to congregate of the white rot sclerotia in the soil which exacerbates the occurrence of white rot [36]. Once the bulb is infected, the plant promptly loses vigor, the leaves turning yellow and wilt, and fluffy, white mycelia fill the bulb and then abundant sclerotia were spotted to increase future infections [37, 38]. The most easily noticeable symptom is the yellowing and dieback of the leaves beginning at the tips and progressing downward accompanied by death of the infected leaves [39].

BARI Rashun-3 scored the maximum disease incidence (29.44\% and $33.33 \%)$ and severity $(63.33 \%$ and $89.33 \%)$ at 60 and 90 DAS. Minimum disease incidence $(5.00 \%)$ and severity $(36.00 \%$ and $60.00 \%)$ founded on Local Indian variety at 60 and 90 DAS. It was similar to Crowe, Hall,
Greathed and Baghott where the incidence of both onion and garlic white rot disease (10-100\%) [40]. The lowest disease incidence of white rot and highest yield in BARI Piaz-3, Indian big and Indian small among nine onion cultivars [41]. BARI Piaz-1 showed lower performance in respect of all parameters. A survey was conducted in different districts of Ethiopia where $97 \%$ of the fields of North Shewa of Ethiopia were infested with white rot. The highest mean disease incidence $(77 \%)$ and severity (57\%) were recorded from the garlic field of Menz Mama Midir as compared to the other districts [42].

Most of the isolates of $S$. cepivorum had cottony fluffy growth on potato dextrose agar. The colony color varied from milky white to cottony watery white. After 10 days of inoculation all the isolates had suppressed growth on PDA media as it is a fast growing pathogen. The result of the study was similar to [43] where the colony color of $S$. vesicarium varied from greenish brown to dirty white, deep grey to whitish, light grey to whitish, raised to flat and texture varying from cottony, fluffy to velvety. Arzanlou, Khodaei and BabaiAhari reported that the colonies of $S$. vesicarium on PCA medium were grey to brownish grey, flat, attaining a diameter of $50 \mathrm{~mm}$ after 7 days with sparse aerial mycelium [44].

\section{Conclusions}

Garlic is considered as the second important spice crop next to onion in Bangladesh and grown under a wide range of favorable condition. Due to pathogenic and environmental factor garlic production is decreasing day by day. The present study was done to determine $\%$ disease incidence and severity owing to white rot and identification of the pathogen for morphological characterization. The study revealed that among eight selected garlic varieties BARI Rashun-3 variety showed the highest disease incidence $(33.33 \%)$ and severity $(89.33 \%)$ whereas, lowest disease incidence $(5 \%)$ and severity $(60 \%)$ was found in Local Indian variety. After 10 
days of incubation in PDA media the growth of the pathogen suppressed the whole petridish. As the pathogen remains viable in the soil more than two decades and introduced by agronomic practices, so farmer should take some precautions. They should maintain a long term rotation schedule, should not follow allium crops with other crops. For the reduction of pathogen colonization they should use row spacing with reduced plant density.

\section{Conflict of Interest}

All authors declare that they have no conflict of interest.

Compliance with ethical standards the present manuscript does not contain any studies with human participants or animals performed by the authors.

\section{Acknowledgements}

We would like to express cordial gratitude to Prof. Dr. Abdur Rahim, Horticulture Department, Bangladesh Agricultural University, Mymensingh and Late Arpon Haider, Scientific officer, Bangladesh Agricultural Research Institute, Joydebpur, Gazipur for providing the different garlic varieties and good cooperation. Special thanks to all the teacher and staffs of Plant Pathology department, Sher-eBangla Agricultural University, Dhaka, Bangladesh for helping throughout the research work.

\section{References}

[1] Rehman R, Saif S, Hanif MA and Riaz M (2019) Medicinal Plant of South Asia. Amsterdam, Elsevier B. V (Chapter 23) Garlic.

[2] Saremi H, Ammarellou A, Saremi H (2010) Garlic white rot caused by Sclerotium cepivorum and its managing by soil solarization in Zanjan province, Northwest Iran. J Food Agric Environ 8: 411-414.

[3] Francisco DH, Angelica MP, Gabriel M, Melchor CS, Raul R, et al. (2011) In vitro antagonist action of Trichoderma strains against Sclerotium cepivorum and Sclerotinia sclerotiorum. Am J Agril biological Sci 6 (3): 410-417.

[4] Castillo H, Rojas RR and Villalta M (2016) Actividad antagonista de Gliocladium sp. contra Sclerotium cepivorum. Tecnología en Marcha 57-54. Doi: 10.18845/tm.v29i7.270.

[5] Nikan J, Heydari A, Naraghi L, Arjmandian A and Mahdizadehnnaraghi R (2018) Application of some fungal bioformulations for controlling garlic white rot disease in the field conditions. Biocontrol Plant Protec 5 (2): 75-83.

[6] Ocegueda-Reyes MD, Casas-Solis J, Virgen-Calleros G, Gonzalez-Eguiarte DR and Lopez-Alcocer E (2019) Isolation, identification and characterization of antagonistic rhizobacteria to Sclerotium cepivorum. Maxican J Phytopathol 38 (1): 1-14. doi: 10.18781/R.MEX.FIT.1911-2.

[7] Nattrass RM (1931) the occurrence of white rot of onion (Sclerotium cepivorm Berk.) in Egypt. Min. of Agric. Tech and Sci. service. (Plant Protect. Section) Bull. 107: 9 (c.f. R. A. M. 11: 219-220, 1993).
[8] Pinto CMF, Maffia LA, Berger RD, Mizubuti ESG, Casali, VWD (1998) Progress of white rot on garlic cultivars planted at different times. Plant Dis 82: 1142-1146.

[9] Earnshaw D, Boland GJ (1997) Mycelial compatibility groups in Sclerotium cepivorum. Plant Pathol 46: 229-238.

[10] Porter IJ, Maughan JP, Towers GB (1991) Evaluation of seed, stem and soil applications of procymidone to control white rot (Sclerotium cepivorum Berk.) of onions. Aust J Experimental Agric 31: 401-6.

[11] Villalta ON, Wite D, Porter IJ, McLean KL, Stewart A and Hunt J (2012) Integrated control of onion white rot on spring onions using diallyl disulphide, fungicides and biocontrols. Acta Horticulturae 944: 63-71.

[12] Couch BC, Kohn L (2000) Clonal spread of Sclerotium cepivorum in onion production with evidence of past recombination events. Phytopathol 90: 514-521.

[13] Tyson JL, Ridgway HJ, Fullerton RA, Stewart A (2002) Genetic diversity in New Zealand populations of Sclerotium cepivorum. New Zealand. J Crop and Hortic Sci 30: 37-48.

[14] Davis RM, Hao JJ, Romberg MK, Nunez JJ, Smith RF (2007) Efficacy of germination stimulants of sclerotia of Sclerotium cepivorum for management of white rot of garlic. Plant Dis 91: 204-208.

[15] Ponce-Herrera V, García-Espinoza R, RodríguezGuzmán MP, Zavaleta-Mejia E (2008) Temporal analysis of white rot (Sclerotium cepivorum Berk.) in onion (Allium cepa L.) under three pathogen inoculum densities./Análisis temporal de la pudrición blanca (Sclerotium cepivorum Berk.) de la cebolla (Allium cepa L.) bajo tres niveles de inóculo del patógeno. Agrociencia (Montecillo) 42: 71-83.

[16] Camiletti BX, Asensio CM, Gadban LC, Pecci MDG, Conies MY, Lucini E (2016) Essential oils and their combinations with iprodione fungicide as potential antifungal agents against withe rot (Sclerotium cepivorum Berk) in garlic (Allium sativum L.) crops. Industrial Crop and Products 85: 117-124.

[17] Amin M, Tadele S, and Selvaraj T (2014) White rot (Sclerotium cepivorum Berk)-an aggressive pest of onion and garlic in Ethiopia: An overview. J Agric Biotech Sustain Dev 6 (1): 6-15.

[18] Elshahawy IE, Saied NM, Abd-El-Kareem F and Morsy AA (2017) Field application of Sclerotial micoparasites as biocontrol agents to Stromatinia cepivora, the cause of onion White rot. J Plant Pathol 99 (2): 391-401. Doi: 10.4454/jpp.v99i2.3888.

[19] Earnshaw D, Donald Mc, Boland GJ (2000) Interaction among isolates and mycelial compatibility groups of Sclerotium cepivorum and cultivars of onion (Allium cepa). $J$ Plant Pathol 22: 387-391.

[20] Fuga CAG, Lopes EA, Vieira BS (2012) Etiologia, epidemiologia e controle de doenças causadas por Sclerotium rolfsii e S. cepivorum. Revisão Anual de Patologia de Plantas 20: $278-322$.

[21] Reis A and Oliveira VR (2013) Identificação e manejo da podridão-branca do alho e da cebola, Embrapa Hortaliças (Comunicado Técnico, 91), Brasília.

[22] Zewide T, Fininsa C, Sakhuja PK (2007) Management of white rot (Sclerotium cepivorum) of garlic using fungicides in Ethiopia. J Crop Protec 26 (6): 856-866. 
[23] Scott MR (1956) Studies of the biology of Sclerotium cepivorum Berk. II. The spread of white rot from plant to plant. Ann Appl Biol 44: 584-589.

[24] Crowe FJ and Hall DH (1980) Soil temperature and moisture effect on sclerotium germination and infection of onion seedlings by Sclerotium cepivorum. Phytopathol 70: 74-78. http://dx.doi.org/10.1094/Phyto-70-74.

[25] Valdir LJR, Vieira BS, Lopes EA and Villalta ON (2018) Etiology, epidemiology, and management of white rot on onion and garlic: current knowledge and future directions for Brazil. Cientifica Jaboticabal 46 (3): 241-256. http://dx.doi.org/10.15361/1984-5529.2018v46n3p241-256.

[26] FAOSTAT. Crops. FAOSTAT. (2021) http:/ww w.fao.org/faostat/en/\#data/QC/.

[27] Worku M, Mashilla D and Azene T (2015) Effectiveness of fungicides to control garlic rust (puccinia allii (rudolphi.)) at Haramaya, Eastern Ethiopia. Int J Advanced Agril Res 1 (1): 16-22.

[28] Manandhar HK, Timila RD, Sharma S, Joshi S, Manandhar S et al. (2016) A field guide for identification and scoring methods of diseases in the mountain crops of Nepal. NARC, LI-BIRD and Bioversity Int P: 12 .

[29] Wheeler BE (1969) An introduction to plant diseases. John Willey and Sons, Ltd., UK Pp. 301.

[30] Islam MR, Akhter N, Chowdhury SM, Ali M and Ahmed KU (2003) Evaluation of Fungicides against Alternaria porri Causing Purple Blotch of Onion. J Agric Sci Technol 2: 27-30.

[31] Clements FE and Shear CL (1957) The genera of fungi. Hafner Publishing Co. New York pp. 496.

[32] Aminuzzaman FM, Hossain I, Ahmed F (2010) Cultural variation and pathogenicity of Bipolaris sorokiniana on wheat in Bangladesh. Int J Agric Environ Biotechnol 3 (1): 76-81.

[33] Ainsworth GC (1971) Dictionary of fungi by Ainsworth and Bisby's. Common Wealth Mycological Institute, Ferrylane, Kew Surrey, UK p. 663.

[34] Gomez KA and Gomez AA (1984) Statistical Procedure for Agricultural Res. (2 ${ }^{\text {nd }}$ Ed.) Manila, Philippines. 139-207.
[35] Painter K, Woodhall J and Jenson J (2019) Beware Signs of White Rot in Garlic and Other Allium Crops. University of Idaho Extension. BUL 955. University of Idaho.

[36] Tamire Z, Cemeda F, Sakuja PK and Seid A (2007) Association of white rot (Sclerotium cepivorum) of garlic with environmental factors and cultural practices in the North Shewa highlands of Ethiopia.

[37] Maude RB (2006) Onion Diseases. In: The Epidemiology of Plant Diseases, Cooke BM, Jones DG and Kaye B, (Eds.) Vol 19. Springer, USA.

[38] Mueller S, Hembree K, Molinar R and Schwankl L (2006) Garlic white rot Trial, 2005/2006 progress report. Retrieved from http://cagarlicandonion.com/page/1003/resources.html. Accessed on April 15, 2018.

[39] Massola Jr NS, Jesus Jr, Kimati H (2016) Doenças do alho e cebola. In: Kimati H, Amorim L, Bergamin Filho A, Camargo LEA, Rezende JAM (Ed.). 5ed. Manual de Fitopatologia: doenças das plantas cultivadas. Piracicaba, Ceres p. 53-65.

[40] Crowe FJ, Hall DH, Greathed AS and Baghott KG (1980) Inoculum density of Sclerotium cepivorum and incidence of white rot of onion and garlic. Phytopathol 70: 64-69.

[41] Das PK (2010) Comparative performance of some selected onion cultivars against Stemphylium vesicarium causing white blotch disease under field condition. Plant Path. Dept. Sher-e Bangla Agril. Univ. pp. 1-49.

[42] Shewakena Z, Hailu L and Desta B (2020) Assessment on incidence and severity of white rot associated with agronomic practice and environmental factors at North Shewa, Central highland of Ethiopia. International Journal of African and Asian Studies 60: 8-12. doi: 10.7176/JAAS/62-02.

[43] Chowdhury NHA (2013) Cultural, morphological and molecular characterization of Stemphylium vesicarium causing white blotch of onion. M.Sc. Thesis, Sher-e-Bangla Agricultural University, Dhaka, Bangladesh.

[44] Arzanlou M, Khodaei S and Babai-Ahari A (2012) Helianthus annuus as a natural host for Stemphylium vesicarium in Iran. Australas. Plant Dis Notes 7: 167-70. 